\title{
Germ Cell Specification and Regeneration in Planarians
}

\author{
P.A. Newmark, Y. WANG, AND T. ChONG \\ Howard Hughes Medical Institute, Department of Cell and Developmental Biology, \\ University of Illinois at Urbana-Champaign, Urbana, Illinois 61801
}

\begin{abstract}
In metazoans, two apparently distinct mechanisms specify germ cell fate: Determinate specification (observed in animals including Drosophila, Caenorhabditis elegans, zebra fish, and Xenopus) uses cytoplasmic factors localized to specific regions of the egg, whereas epigenetic specification (observed in many basal metazoans, urodeles, and mammals) involves inductive interactions between cells. Much of our understanding of germ cell specification has emerged from studies of model organisms displaying determinate specification. In contrast, our understanding of epigenetic/inductive specification is less advanced and would benefit from studies of additional organisms. Freshwater planarians - widely known for their remarkable powers of regeneration - are well suited for studying the mechanisms by which germ cells can be induced. Classic experiments showed that planarians can regenerate germ cells from body fragments entirely lacking reproductive structures, suggesting that planarian germ cells could be specified by inductive signals. Furthermore, the availability of the genome sequence of the planarian Schmidtea mediterranea, coupled with the animal's susceptibility to systemic RNA interference (RNAi), facilitates functional genomic analyses of germ cell development and regeneration. Here, we describe recent progress in studies of planarian germ cells and frame some of the critical unresolved questions for future work.
\end{abstract}

Since the late 19th century, when Weismann proposed that an immortal germ line was propagated from generation to generation, producing a mortal soma at each generation, developmental biologists have been fascinated by the question of how the germ cell lineage is established during embryogenesis (Weismann 1893; McLaren 1981; Extavour 2007). In addition to serving as a link between generations, the germ cells represent an intriguing example of cellular differentiation, in which highly differentiated cell types maintain their totipotency and are capable of reproducing themselves indefinitely (Rando 2006; Seydoux and Braun 2006; Cinalli et al. 2008).

Two apparently distinct modes of germ cell specification are typically observed in animals. Determinate specification (or preformation) refers to germ cell specification by localized maternal determinants early in embryogenesis (Nieuwkoop and Sutasurya 1981; Extavour and Akam 2003; Seydoux and Braun 2006; Extavour 2007). Determinate specification is observed in the most commonly studied invertebrates, Drosophila and C. elegans (for review, see Seydoux and Schedl 2001; Santos and Lehmann 2004), as well as in some vertebrates, including anuran amphibians (Houston and King 2000) and zebra fish (Raz 2003). In these animals, specialized cytoplasm (the germ plasm) is associated with germ cell formation (Eddy 1975). This cytoplasm contains granular inclusions consisting of RNA and protein; these granules are known as polar granules in flies, $\mathrm{P}$ granules in nematodes, and germinal granules in frogs, or more generally, as germ granules (Seydoux and Braun 2006).

In contrast to determinate specification, many organisms use inductive interactions to specify their germ cell lineage relatively late in embryogenesis. This epigenetic specification is observed in mammals as well as in a wide range of basal invertebrates and other vertebrate species (Nieuwkoop and Sutasurya 1979, 1981; Extavour and Akam 2003; Hayashi et al. 2007). Phylogenetic surveys suggest that this mode is more widespread throughout the metazoa and is likely to be ancestral (Extavour and Akam 2003; Johnson et al. 2003; Extavour 2007). Although this usage of the term "epigenetic" accurately reflects the original meaning of the term "epigenesis," this word is now more commonly used to signify, "...a change in the state of expression of a gene that does not involve a mutation, but that is nevertheless inherited in the absence of the signal (or event) that initiated the change" (Ptashne 2007). To minimize confusion and to avoid the unintended mechanistic implications of the term "epigenetic specification," we refer to this mode of specification as "inductive specification" (Seydoux and Braun 2006).

Much of the progress made in understanding the mechanisms of germ cell determination has been driven by genetic analyses in Drosophila and C. elegans. Thus, numerous components of the Drosophila germ plasm have been identified, along with factors that are required for their localization to the posterior pole of the embryo (StarzGaiano and Lehmann 2001). Likewise, genetic analyses in C. elegans also have identified components of the germ plasm and revealed the importance of transcriptional repression mechanisms during the early stages of germ cell formation (Seydoux and Strome 1999). Many genes identified from these model invertebrates have been conserved evolutionarily. For example, homologs of Drosophila $v a s a$, a gene encoding a DEAD-box RNA helicase that is a component of the polar granules (Hay et al. 1988; Lasko and Ashburner 1988), are expressed in germ cells in Xenopus (Komiya et al. 1994; Ikenishi and Tanaka 1997), zebra fish (Olsen et al. 1997; Yoon et al. 1997), and chick (Tsunekawa et al. 2000), as well as C. elegans (Gruidl et al. 1996) and numerous other organisms (Shibata et al. 1999; Mochizuki et al. 2001; Extavour and Akam 2003; Extavour et al. 2005). Similarly, homologs of Drosphila nanos, which encodes a $\mathrm{CCHC}$ zinc finger RNA-binding protein required for abdominal segmentation as well as germ cell 
differentiation and maintenance (Lehmann and NüssleinVolhard 1991; Wang and Lehmann 1991; Kobayashi et al. 1996; Forbes and Lehmann 1998; Deshpande et al. 1999; Hayashi et al. 2004), also serve as markers of germ cells throughout the metazoa (Extavour and Akam 2003; Extavour et al. 2005; Juliano et al. 2006).

Although mammalian germ cell formation requires inductive signaling rather than maternally supplied determinants (Hayashi et al. 2007), homologs of these and several other Drosophila genes also have roles in mammalian germ cells. In the mouse, nanos 3 is expressed in primordial germ cells soon after they are formed in both sexes, whereas nanos 2 is expressed in male primordial germ cells after they have migrated to the genital ridge (Tsuda et al. 2003). Knockout mutations of nanos 3 result in germ cell loss in both sexes and nanos 2 knockouts result in loss of spermatogonia (Tsuda et al. 2003; Suzuki et al. 2007). Like nanos2, the mouse vasa homolog is not expressed in primordial germ cells until they arrive at the genital ridge (Fujiwara et al. 1994; Toyooka et al. 2000) and knockouts of this gene do not result in defects in germ cell specification, but they cause male-specific defects in germ cell proliferation and/or survival (Tanaka et al. 2000). Additional mouse homologs of Drosophila polar granule components have been shown to be associated with chromatoid bodies, the germ granules of mammalian spermatocytes. These conserved molecules include tudor-domain proteins (Chuma et al. 2006; Hosokawa et al. 2007), components of the microRNA pathway, such as the products of piwi and argonaute genes, and various components of processing (P) bodies, sites at which untranslated mRNAs accumulate in somatic cells (Kotaja et al. 2006).

Despite the identification of many conserved components and the realization that general regulatory mechanisms are shared between inductive and determinate specification (e.g., transcriptional repression of somatic gene expression, chromatin remodeling to a generally repressive state, and an emphasis on posttranscriptional control mechanisms [Seydoux and Braun 2006; Cinalli et al. 2008]), several critical questions remain unanswered. What are the mechanisms that activate expression of germ cell-specific genes in the earliest stages of primordial germ cell formation? Are there conserved inductive signals that specify germ cell fate? Because mechanistic studies of inductive specification have been limited to the mouse, virtually nothing is known about the identity of germ cell-inducing signals in other organisms. In the mouse, bone morphogenetic protein (BMP) signaling from the extraembryonic ectoderm is required for primordial germ cell formation (Lawson et al. 1999; Ying et al. 2000). However, this signaling may be acting indirectly through the visceral endoderm, rather than directly upon cells of the proximal epiblast (de Sousa Lopes et al. 2004); thus, the nature of the inductive signal(s) is still not entirely clear. How is totipotency established and maintained in germ cells? The demonstration that germ-line stem cells from mouse neonatal testes (KanatsuShinohara et al. 2004) and spermatogonial stem cells from adult testes (Guan et al. 2006; Seandel et al. 2007) can generate pluripotent cells with developmental potential similar to that of embryonic stem (ES) cells hints at the therapeutic applications that could result from answering the above questions.

To answer such questions and expand our understanding of the inductive specification of germ cell fate, we are using the freshwater planarian as a model organism. Planarians are well known for regenerative abilities that enable them to produce a complete organism from a tiny fragment of the body. The fact that their germ cell lineage can also be regenerated is less well appreciated and forms the basis for this work. Before discussing the current state of our knowledge and outlining important areas for future research, it is first necessary to review briefly the salient aspects of planarian biology, as well as the recent technical advances that pave the way for a mechanistic analysis of germ cell development in these organisms.

\section{INTRODUCTION TO PLANARIAN BIOLOGY}

The remarkable regenerative abilities of planarians have led generations of biologists to study these organisms (Newmark and Sánchez Alvarado 2002; Reddien and Sánchez Alvarado 2004; Sánchez Alvarado 2006). Planarians are free-living, freshwater members of the phylum Platyhelminthes (the flatworms). Flatworms are among the simplest animals with three tissue layers (triploblasts) that display bilateral symmetry, an anterior concentration of neural tissue (cephalization), and the organization of specialized tissues into organs. Flatworms lack respiratory and circulatory systems and instead rely on diffusion to obtain oxygen. The planarian nervous system consists of bilobed cerebral ganglia at the anterior end and two longitudinal nerve cords that underlie the ventral body wall musculature and run the length of the animal (Agata et al. 1998; Okamoto et al. 2005; Cebria 2008). Sensory structures (photoreceptors, chemoreceptors) located at the anterior of the animal send projections to the cephalic ganglia, which then process external signals and direct the appropriate behavioral responses (MacRae 1967; Inoue et al. 2004).

Freshwater planarians reproduce either asexually, by transverse fission, or sexually, as cross-fertilizing hermaphrodites (Hyman 1951). Some planarians use exclusively one mode of reproduction, and others may alternate among them depending on the season. In the asexual mode of reproduction, the worm splits itself transversely into two fragments, each of which regenerates the missing tissue, thereby producing two planarians. This behavior can be regulated both by the physiological state of the animal and by external stimuli (e.g., population density and darkness) (Pigon et al. 1974; Morita and Best 1984). In the sexual mode, hermaphrodites cross-fertilize and then lay egg capsules that contain several embryos. In hermaphrodites, numerous testes are distributed dorsolaterally (Fig. 1a) and the ovaries are situated at the posterior region of the cephalic ganglia (Fig. 1b). Individual lobes of the testes (Fig.1c) possess an outer layer of spermatogonia that undergo three rounds of division with incomplete cytokinesis, generating eight primary spermatocytes that progress through meiosis to generate 32 spermatids (Franquinet and Lender 1973). Spermiogenesis packages the DNA in elongated sperm ( $\sim 100 \mu \mathrm{m}$ in length) with two $9+1$ flagella at the anterior 

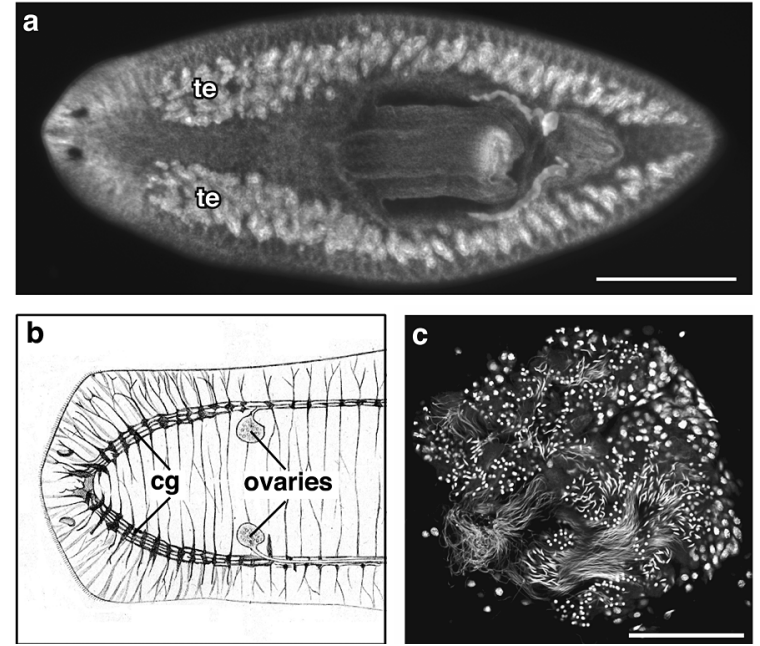

Figure 1. Reproductive organs in sexually reproducing planarians. (a) DAPI (4'-diamidino-2-phenylindole) labeling to visualize dorsolateral testes (te) clusters in a whole-mount specimen of S. mediterranea. Bar, $1 \mathrm{~mm}$. (b) Position of the ovaries relative to the cephalic ganglia (cg) in S. polychroa. (c) Confocal projection of individual testis lobe from $S$. mediterranea labeled with Hoechst. Different stages of spermatogenesis and elongated spermatozoa are easily observed. Bar, $100 \mu \mathrm{m}$. ( $b$, Adapted from Iijima [1884].)

end (Silveira and Porter 1964). Ciliated oviducts run along the nerve cords to transport fertilized eggs to the region posterior to the pharynx, where the copulatory apparatus and genital pore are located. Sperm ducts also project along the nerve cords, connecting individual testis lobes to the seminal vesicles and copulatory apparatus. In sexually reproducing planarians, the germ cell lineage does not appear to be segregated during embryogenesis; rather, when the planarian attains the appropriate size, gonads and the copulatory apparatus develop in the appropriate regions of the worm (Curtis 1902).

The developmental plasticity displayed by planarians is based on a population of stem cells that is maintained in the animal throughout adult life. These stem cells are referred to as neoblasts and they are the only proliferating somatic cells in the worm (Baguñà 1976; Newmark and Sánchez Alvarado 2000; Salvetti et al. 2000; Orii et al. 2005). In intact planarians, neoblasts are scattered throughout the parenchyma (mesenchyme) and their division progeny generate replacements for cells lost during the course of physiological cell turnover. When a planarian is transected, the neoblasts are stimulated to proliferate; as the neoblasts migrate toward the wound epithelium, they give rise to the regeneration blastema, the structure in which the missing parts will be regenerated (Agata and Watanabe 1999; Newmark and Sánchez Alvarado 2002; Reddien and Sánchez Alvarado 2004; Sánchez Alvarado 2006).

The regenerative abilities of planarians are not limited to their somatic tissues: They are also capable of regenerating their germ cells de novo. T.H. Morgan (1902) showed that a planarian head fragment, completely devoid of any reproductive structures, could regenerate functional gonads from the remaining somatic tissue (Fig. 2). Thus,

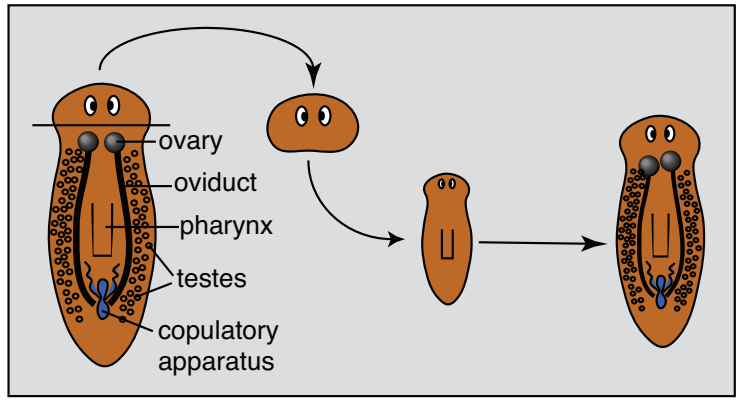

Figure 2. Regeneration of the planarian reproductive system from a fragment lacking all reproductive tissues. Amputation anterior to all of the reproductive structures produces a head fragment devoid of reproductive organs. This fragment will regenerate a complete animal; when it reaches the appropriate size, it will regenerate the gonads and the copulatory aparatus. (Adapted from an experiment described by Morgan [1902].)

Morgan concluded that the germ cell lineage could be derived from somatic cells in these animals. During the degrowth (shrinkage) that is the planarian's response to starvation, the gonads and copulatory apparatus are resorbed (Schultz 1904; Berninger 1911), only to be regenerated when the animal reaches the appropriate size after feeding is resumed. Treatment with sublethal doses of $\gamma$-irradiation also leads to regression of the testes, followed by their regeneration (Fedecka-Bruner 1965, 1967). Following amputation of the head of sexually mature animals, the testes are resorbed and are only reformed after regeneration of the cephalic ganglia is complete (Ghirardelli 1965). Thus, inductive influences from the brain appear to be important for sexual differentiation.

\section{THE PLANARIAN SCHMIDTEA MEDITERRANEA: AN EMERGING MODEL ORGANISM}

Of the hundreds of species of free-living planarians, $S$. mediterranea has emerged as the model of choice for functional genomic analyses of regeneration (Newmark and Sánchez Alvarado 2002; Sánchez Alvarado 2006). It is a stable diploid, with a genome size of $8 \times 10^{8} \mathrm{bp}$ (data from S. Johnston, Texas A\&M University, and the Washington University Genome Sequencing Center [WUGSC]). In contrast, the common North American species often found in biology classrooms are mixoploids (mosaics of diploid and triploid cells) and have genomes that are about twice as large as that of $S$. mediterranea. Two strains of this species are found in nature: a sexual strain that reproduces as cross-fertilizing hermaphrodites and an asexual strain that reproduces via transverse fission. These strains can be distinguished genetically by a chromosomal translocation present in the asexual strain (Benazzi et al. 1975). Clonal lines of both strains have been used to produce expressed sequence tags (ESTs) from various tissues and regenerative stages of asexual animals (Sánchez Alvarado et al. 2002) and from developing juveniles and reproductively mature sexual animals (Zayas et al. 2005). The genome of the sexual strain has been sequenced to $11.6 \mathrm{x}$ coverage by whole-genome 
shotgun sequencing and a genome assembly is now available (WUGSC). The genome has been annotated using an automated annotation pipeline (Cantarel et al. 2008); the annotation data are available via the Schmidtea mediterranea genome database (SmedGD), maintained by the Sánchez Alvarado laboratory at the University of Utah (Robb et al. 2008).

The application of the tools of cellular and molecular biology has opened up a new era in studies of freshwater planarians (Newmark and Sánchez Alvarado 2002). It is now possible to identify and functionally characterize the genes required for regulating developmental processes in these animals. Gene expression in planarians can be inhibited specifically by RNA interference (RNAi), by either microinjection (Sánchez Alvarado and Newmark 1999) or feeding bacterially expressed double-stranded RNA (dsRNA) (Newmark et al. 2003; Reddien et al. 2005a). Because the neoblasts are the only proliferating somatic cells in the animal, they can be labeled specifically with bromodeoxyuridine (Newmark and Sánchez Alvarado 2000). Fluorescence-activated cell sorting (FACS) methodologies have been developed by Kiyokazu Agata's laboratory to isolate neoblasts and other planarian cell types (Asami et al. 2002; Hayashi et al. 2006). Automated whole-mount in situ hybridization techniques have been developed for high-throughput localization of gene expression patterns with single-cell resolution (Sánchez Alvarado et al. 2002; Zayas et al. 2005).

The functional genomic resources now at our disposal provide us with tremendous tools for discovering the genetic programs that underlie regeneration in planarians. The utility of these tools has already been borne out by the identification of several genes that are conserved between planarians and mammals and that are required for proper regulation of the planarian stem cell population (Cebria et al. 2002; Reddien et al. 2005a,b; Salvetti et al. 2005; Guo et al. 2006; Palakodeti et al. 2008).

\section{NANOS FUNCTION IS REQUIRED FOR THE DEVELOPMENT AND REGENERATION OF GERM CELLS IN PLANARIANS}

As described above, classic experiments suggested that planarians can regenerate their germ cell lineage; the neoblasts appear to be the source of newly regenerated germ cells. To understand the switch from somatic stem cell to germ cell, we characterized an $S$. mediterranea homolog of nanos, a gene required for germ cell development in widely divergent organisms. Homologs of nanos are expressed in the germ cell lineage of all animals studied to date; nanos expression is used routinely to identify early germ cells (Extavour and Akam 2003; Extavour et al. 2005; Juliano et al. 2006). In sexual S. mediterranea, Smed-nanos mRNA is detected in developing, regenerating, and mature ovaries and testes (Handberg-Thorsager and Saló 2007; Wang et al. 2007). A similar pattern was also reported for a nanos homolog from another planarian species, Dugesia japonica (Sato et al. 2006). However, consistent with an inductive origin of the germ cells, nanos RNA is not detected in the vast majority of newly hatched planarians or in small tissue fragments that will ultimately regenerate germ cells (Sato et al. 2006; Wang et al. 2007).

To analyze the function of nanos in planarian germ cells, we assayed the effects of nanos RNAi upon regeneration of the reproductive organs. Mature animals were fed twice with nanos dsRNA and then amputated posterior to the ovaries to trigger regression of the testes; regeneration of the testes and ovaries could then be monitored. Feeding of dsRNA was resumed 2 weeks after amputation to allow the animals to grow and undergo sexual maturation. Control planarians fed bacteria containing vector alone showed proper regeneration of somatic tissues and reproductive organs. Worms fed nanos dsRNA displayed normal regeneration of their somatic tissues; however, they did not regenerate reproductive organs as assayed by several markers of germ cells at various stages of differentiation (Wang et al. 2007).

When newly hatched planarians were reared on food containing nanos dsRNA, they failed to develop testes or ovaries. Similarly, when sexually mature planarians were subjected to nanos RNAi, the testes and ovaries degenerated over the course of several weeks, resulting in animals that lacked gonads (Fig. 3). Together, our results showed that nanos is required for the postembryonic development, regeneration, and maintenance of planarian germ cells.

\section{PRESUMPTIVE GERM CELLS IN ASEXUAL PLANARIANS}

Surprisingly, nanos RNA was also detected in the asexual strain of $S$. mediterranea; nanos-positive cell clusters were found dorsolaterally, in the position of testes primordia in hermaphrodites (Handberg-Thorsager and Saló 2007; Wang et al. 2007). This pattern was also described in the asexual strain of the planarian D. japonica; however, no functional data were reported (Sato et al. 2006). Because nanos is expressed in germ cells from widely divergent metazoan phyla (Extavour and Akam 2003) and the nanos-positive cells observed in asexual planarians are located in positions at which germ cells are first observed postembryonically in sexual planarians, we refer to these cells as presumptive germ cells. These
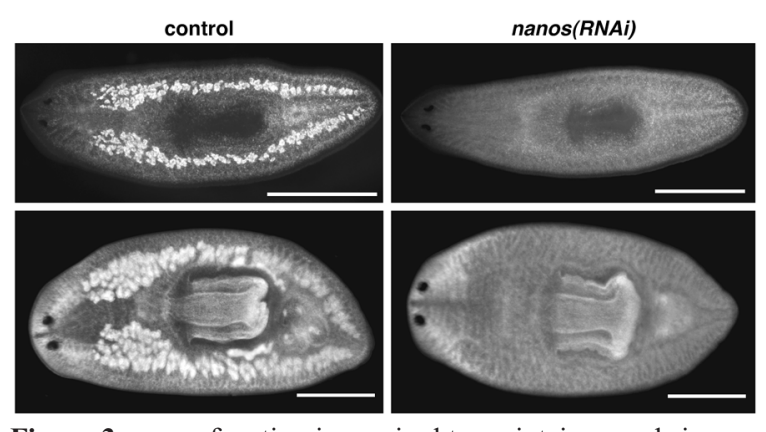

Figure 3. nanos function is required to maintain gonads in sexually mature planarians. (Upper panels) Fluorescent in situ hybridization to detect germinal histone H4 RNA in control and nanos (RNAi) animals, 30 days after initiation of RNAi. (Lower panels) DAPI staining revealing testes in control animals but not in nanos (RNAi) animals. Bars, $1 \mathrm{~mm}$. 

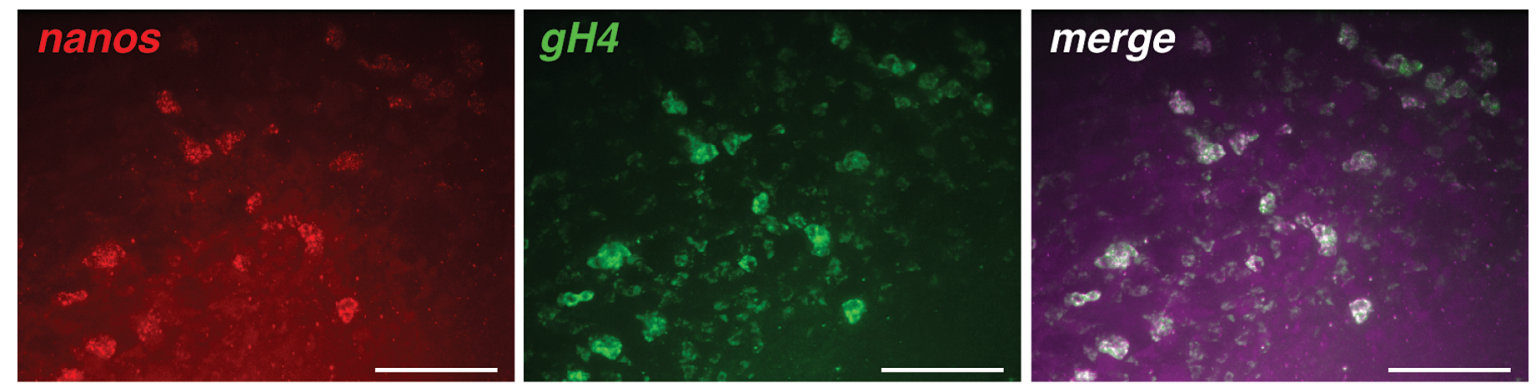

Figure 4. Coexpression of nanos and germinal histone $H 4(\mathrm{gH} 4)$ mRNAs in the presumptive germ cells of asexual planarians as visualized by whole-mount double fluorescent in situ hybridization. Individual fluorescent channels and the merged images are shown. Bars, $60 \mu \mathrm{m}$.

nanos-positive presumptive germ cells express high levels of germinal histone H4 (germinal H4) (Fig. 4), a marker of both male and female germ cells in sexual planarians (Zayas et al. 2005; Wang et al. 2007). The germinal $\mathrm{H} 4$ riboprobe also labels neoblasts, albeit more weakly (Fig. 4) (Wang et al. 2007), possibly due to crosshybridization with somatic histone $H 4$ transcripts (Wolfe et al. 1989). In addition, these clusters express a planarian Piwi protein, Smedwi-1, which labels neoblasts as well as their committed progeny (Guo et al. 2006; Guo 2007). Expression of both nanos and germinal H4 in asexual planarians is $\gamma$-radiation-sensitive, suggesting either that the presumptive germ cells are actively cycling or that they are derived from proliferating cells.

To test the role of nanos in asexual planarians, we performed RNAi. After nanos knockdown and amputation, somatic tissue regeneration proceeded normally: Head and tail regeneration were unaffected and cephalic ganglia and photoreceptors formed properly; similarly, germinal H4 labeling of the neoblasts was unaffected. However, the dorsolateral germinal-H4-positive clusters were lost (Wang et al. 2007). Similarly, dorsolateral germinal H4 clusters were lost after subjecting intact asexual planarians to nanos RNAi (Fig. 5). Thus, nanos function is required for the regeneration and maintenance of presumptive germ cells in asexual planarians. These results suggest that asexual planarians specify germ cells, but their differentiation is blocked at a step downstream from nanos function.

\section{NEOBLASTS SHARE SEVERAL FEATURES WITH GERM CELLS}

Transplantation experiments in which cell fractions enriched in neoblasts were introduced into lethally irradiated planarians suggested that neoblasts are capable of generating both somatic and germ cell lineages (Baguñà et al. 1989). This notion is supported by the regeneration of nanos-positive presumptive germ cells described above. Given the apparent ability of neoblasts to produce germ cells, it is reasonable to ask to what extent these somatic stem cells are themselves similar to germ cells. As viewed by transmission electron microscopy, the somatic neoblasts of $D$. japonica are morphologically indistinguishable from nanos-positive presumptive germ cells in asexual individuals (Sato et al. 2006). Ultrastructural analyses revealed that the cytoplasm of neoblasts contains chromatoid bodies, which are electron-dense ribonucleoprotein particles that resemble the germ granules found in germ cells (Le Moigne 1967; Sauzin 1968; Morita et al. 1969; Hay and Coward 1975; Hori 1982; Auladell et al. 1993). Like germ granules, the chromatoid bodies can be found in association with mitochondria and the nuclear envelope. Chromatoid bodies diminish as neoblasts differentiate (Sauzin 1968; Morita et al. 1969; Hay and Coward 1975; Hori 1982). Furthermore, several genes with conserved roles in germ cell development are expressed in neoblasts, including homologs of vasa, piwi, pumilio, and bruno (Shibata et al. 1999; Reddien et al. 2005b; Salvetti et al. 2005; Guo et al. 2006; Rossi et al. 2006; YoshidaKashikawa et al. 2007; Palakodeti et al. 2008). Thus, the pluripotent neoblasts appear poised to adopt germ cell fate(s). As observed in more basal metazoans (e.g., sponges, cnidarians, and acoels), this pluripotent stem cell pool provides the source of the germ cell lineage, consistent with the notion that the germ line may have arisen initially from somatic stem cells (Extavour 2007).
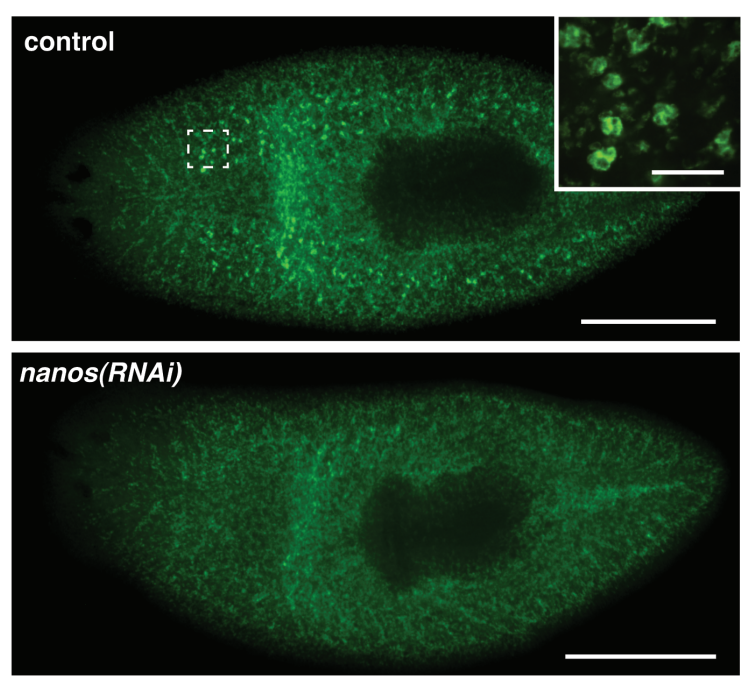

Figure 5. nanos function is required to maintain presumptive germ cells in asexual planarians. Fluorescent in situ hybridization to detect germinal H4 RNA in control and nanos (RNAi) animals 35 days after initiation of RNAi. (Inset) Magnified image of boxed region showing germinal-histone-H4-positive clusters of presumptive germ cells observed in control animals but absent in nanos (RNAi) animals. Bars, $500 \mu \mathrm{m}$; (inset) $50 \mu \mathrm{m}$. 


\section{PLASTICITY OF PLANARIAN GERM CELLS AND COMMITTED NEOBLASTS?}

Given the relatively large numbers of cells in the planarian that can be defined morphologically as neoblasts, it is unlikely that all of these cells represent true stem cells (Baguñà et al. 1990). Rather, most of these cells may already be committed to specific fates, with only a small fraction representing true stem cells. Heterogeneity of this cell population is supported by electron microscopic analysis of fluorenscence-activated cell-sorted planarian cells (Higuchi et al. 2007).

To what extent are the committed progeny locked into their "assigned" fates? There are two lines of evidence for some degree of plasticity within the pool of neoblast progeny: One involves the germ cell lineage; the other, the somatic lineage. Experiments conducted by Gremigni and coworkers suggested that the planarian germ cell lineage was capable of contributing to the regeneration blastema and producing somatic cells (Gremigni and Puccinelli 1977; Gremigni and Miceli 1980; Gremigni et al. 1980a,b). These experiments used a mosaic strain of Dugesia lugubris (Schmidtea polychroa) in which the somatic cells are triploid. This pseudogamous strain produces triploid oocytes that are activated by haploid sperm; after activation, the sperm pronucleus is expelled from the egg. Thus, in these animals, the premeiotic female germ cells are hexaploid, whereas neoblasts that give rise to male germ cells undergo a round of chromosomal elimination, generating diploid premeiotic germ cells that produce haploid sperm (Benazzi Lentati 1970).

Using both karyological and cytophotometric analyses, Gremigni and his colleagues (1980a) reported that, depending on the level of amputation (i.e., whether the gonads had been transected before amputation), diploid and/or hexaploid cells were found to contribute to the blastema and could be observed among differentiated cell types (e.g, cells of the pharynx; Gremigni and Miceli 1980), suggesting that the germ cells could trans-differentiate to produce somatic cell types. Similarly, following amputation and regeneration of the ovaries, tetraploid oocytes were produced, albeit at low frequency (3.2\%); uninjured, unamputated animals did not produce such tetraploid oocytes. The authors suggested that the tetraploid oocytes were derived from diploid male germ cells that had been mobilized by amputation and changed their fates to generate female germ cells (Gremigni et al. 1982).

Several recent observations suggest that this plasticity of committed germ cells is not limited to planarians. Drosophila spermatogonia (Brawley and Matunis 2004) and ovarian cystoblasts (Kai and Spradling 2004) are capable of reverting to germ-line stem cells after initiating differentiation and exiting their niches. Similarly, when cultured in vitro, germ-line stem cells from mouse neonatal testes (Kanatsu-Shinohara et al. 2004) and spermatogonial stem cells from adult testes (Guan et al. 2006; Seandel et al. 2007) can produce pluripotent cells similar to ES cells.

In addition to the apparent plasticity of committed germ cells, evidence for plasticity of somatic neoblast progeny comes from classic blastema explant culture experiments performed by Sengel (1960). When 3-day anterior blastemas were surgically isolated from the rest of the nonregenerating tissues and cultured in vitro, they were capable of differentiating to form pigment, muscles, and anterior structures, such as photoreceptors and cephalic ganglia. Thus, at this relatively early stage of regeneration, the cells of the anterior blastema were already specified to make head structures. When early posterior blastemas at a similar stage were cultured in vitro, they formed muscle and pigment but did not produce photoreceptors or cephalic ganglia. Intriguingly, when anterior blastemas were cocultured with posterior blastemas, they gave rise to small planarians in which the central body region (pharynx) and gut were formed. Thus, the juxtaposition of anterior and posterior blastemas led to the intercalary regeneration of central body structures. It is important to note that in planarians, proliferation does not occur in the blastema (Saló and Baguñà 1984, 1989); rather, neoblasts proliferate in the stump and postmitotic neoblast progeny migrate into the blastema. The explant experiments showed that these postmitotic blastemal cells are specified early in regeneration. However, this specification (and perhaps cell cycle exit) could be reversed by juxtaposing cells from anterior and posterior regions, suggesting that the fates of specified neoblast progeny can be altered by changes in extracellular signals. If this is the case, then it is possible that a relatively large population of neoblast progeny committed to specific developmental pathways - required for maintaining tissues during the course of cell turnover - may be able to reverse their state of commitment following amputation and generate additional pluripotent cells. As we refine the tools for labeling individual cells and following their fates in the animal, it will be worth reexploring this issue.

\section{CONCLUSIONS}

In the last decade, great strides have been made in developing freshwater planarians as models for studying stem cell biology, metazoan regeneration, and tissue homeostasis. In this brief overview, we have described many aspects of the biology of $S$. mediterranea that make it well suited for examining another fundamental problem in developmental biology: specification of the germ cell lineage. The demonstration that planarian germ cells can be regenerated de novo, combined with the functional genomic tools available for studying $S$. mediterranea, provides us with an exceptional opportunity to dissect the molecular mechanisms by which inductive signals can specify germ cell fate. Several important questions can now be addressed experimentally in this animal, including: What is the nature of the inductive signal and has it been conserved evolutionarily? What intrinsic changes in gene expression direct the transition from somatic stem cell to germ cell in response to the inductive signal(s)? Why are presumptive germ cells unable to complete their differentiation in asexual $S$. mediterranea? What mechanisms lead germ cells to follow male versus female differentiation pathways in these hermaphroditic organisms? How are physiological/metabolic signals coupled with 
meiotic entry, germ cell differentiation, and maintenance of the gonads? How plastic are the fates of committed neoblasts and differentiating germ cells in these animals? As the cohort of researchers interested in studying these fascinating animals continues to expand, we look forward to the answers that will emerge.

\section{ACKNOWLEDGMENTS}

We thank David Forsthoefel, Tingxia Guo, Joel Stary, and Ricardo Zayas for helpful discussions and David Forsthoefel and Ricardo Zayas for constructive suggestions on various drafts of the manuscript. Work in P.A.N.'s laboratory has been funded by grants from the National Institutes of Health, National Science Foundation, and the Damon Runyon Cancer Research Foundation. P.A.N. is an Investigator of the Howard Hughes Medical Institute.

\section{REFERENCES}

Agata, K. and Watanabe, K. 1999. Molecular and cellular aspects of planarian regeneration. Semin. Cell Dev. Biol. 10: $377-383$.

Agata, K., Soejima, Y., Kato, K., Kobayashi, C., Umesono, Y., and Watanabe, K. 1998. Structure of the planarian central nervous system (CNS) revealed by neuronal cell markers. Zoolog. Sci. 15: 433-440.

Asami, M., Nakatsuka, T., Hayashi, T., Kou, K., Kagawa, H., and Agata, K. 2002. Cultivation and characterization of planarian neuronal cells isolated by fluorescence activated cell sorting (FACS). Zoolog. Sci. 19: 1257-1265.

Auladell, C., Garcia-Valero, J., and Baguñà, J. 1993. Ultrastructural localization of RNA in the chromatoid bodies of undifferentiated cells (neoblasts) in planarians by the RNase-gold complex technique. J. Morphol. 216: 319-326.

Baguñà, J. 1976. Mitosis in the intact and regenerating planarian Dugesia mediterranea n.sp. I. Mitotic studies during growth, feeding and starvation. J. Exp. Zool. 195: 53-64.

Baguñà, J., Saló, E., and Auladell, C. 1989. Regeneration and pattern formation in planarians. III. Evidence that neoblasts are totipotent stem cells and the source of blastema cells. Development 107: 77-86.

Baguñà, J., Romero, R., Saló, E., Collet, J., Auladell, C., Ribas, M., Riutort, M., Garcia-Fernàndez, J., Burgaya, F., and Bueno, D. 1990. Growth, degrowth and regeneration as developmental phenomena in adult freshwater planarians. In Experimental embryology in aquatic plants and animals (ed. H.-J. Marthy), pp. 129-162. Plenum, New York.

Benazzi, M., Baguñà, J., Ballester, R., Puccinelli, I., and Del Papa, R. 1975. Further contribution to the taxonomy of the "Dugesia lugubris-polychroa group" with description of Dugesia mediterranea n.sp. (Tricladida, Paludicola). Boll. Zool. 42: 81-89.

Benazzi Lentati, G. 1970. Gametogenesis and egg fertilization in planarians. Int. Rev. Cytol. 27: 101-179.

Berninger, J. 1911. Über die Einwirkung des Hungers auf Planarien. Zool. Jahrb. 30: 181-216.

Brawley, C. and Matunis, E. 2004. Regeneration of male germline stem cells by spermatogonial dedifferentiation in vivo. Science 304: 1331-1334.

Cantarel, B.L., Korf, I., Robb, S.M., Parra, G., Ross, E., Moore, B., Holt, C., Sánchez Alvarado, A., and Yandell, M. 2008. MAKER: An easy-to-use annotation pipeline designed for emerging model organism genomes. Genome Res. 18: 188-196.

Cebria, F. 2008. Organization of the nervous system in the model planarian Schmidtea mediterranea: An immunocytochemical study. Neurosci. Res. 61: 375-384.

Cebria, F., Kobayashi, C., Umesono, Y., Nakazawa, M., Mineta,
K., Ikeo, K., Gojobori, T., Itoh, M., Taira, M., Sánchez Alvarado, A., and Agata, K. 2002. FGFR-related gene noudarake restricts brain tissues to the head region of planarians. Nature 419: 620-624.

Chuma, S., Hosokawa, M., Kitamura, K., Kasai, S., Fujioka, M., Hiyoshi, M., Takamune, K., Noce, T., and Nakatsuji, N. 2006. Tdrd1/Mtr-1, a tudor-related gene, is essential for male germcell differentiation and nuage/germinal granule formation in mice. Proc. Natl. Acad. Sci. 103: 15894-15899.

Cinalli, R.M., Rangan, P., and Lehmann, R. 2008. Germ cells are forever. Cell 132: 559-562.

Curtis, W.C. 1902. The life history, the normal fission, and the reproductive organs of Planaria maculata. Proc. Boston Soc. Nat. Hist. 30: 515-560.

Deshpande, G., Calhoun, G., Yanowitz, J.L., and Schedl, P.D. 1999. Novel functions of nanos in downregulating mitosis and transcription during the development of the Drosophila germline. Cell 99: 271-281.

de Sousa Lopes, S.M., Roelen, B.A., Monteiro, R.M., Emmens, R., Lin, H.Y., Li, E., Lawson, K.A., and Mummery, C.L. 2004. BMP signaling mediated by ALK2 in the visceral endoderm is necessary for the generation of primordial germ cells in the mouse embryo. Genes Dev. 18: 1838-1849.

Eddy, E.M. 1975. Germ plasm and the differentiation of the germ cell line. Int. Rev. Cytol. 43: 229-280.

Extavour, C.G.M. 2007. Evolution of the bilaterian germ line: Lineage origin and modulation of specification mechanisms. Integr. Comp. Biol. 47: 770-785.

Extavour, C.G. and Akam, M. 2003. Mechanisms of germ cell specification across the metazoans: Epigenesis and preformation. Development 130: 5869-5884.

Extavour, C.G., Pang, K., Matus, D.Q., and Martindale, M.Q. 2005. vasa and nanos expression patterns in a sea anemone and the evolution of bilaterian germ cell specification mechanisms. Evol. Dev. 7: 201-215.

Fedecka-Bruner, B. 1965. Régénération des testicules des planaires après destruction par les rayons X. In Regeneration in animals and related problems (ed. V. Kiortsis and H.A.L. Trampusch), pp. 185-192. North-Holland, Amsterdam.

Fedecka-Bruner, B. 1967. Études sur la régénération des organes genitaux chez la planaire Dugesia lugubris. I. Régénération des testicules après destruction. Bull. Biol. Fr. Belg. 101: 255-319.

Forbes, A. and Lehmann, R. 1998. Nanos and Pumilio have critical roles in the development and function of Drosophila germline stem cells. Development 125: 679-690.

Franquinet, R. and Lender, T. 1973. Étude ultrastructurale des testicules de Polycelis tenuis et Polycelis nigra (Planaires). Evolution des cellules germinales mâles avant la spermiogenèse. Z. Mikrosk. Anat. Forsch. 87: 4-22.

Fujiwara, Y., Komiya, T., Kawabata, H., Sato, M., Fujimoto, H., Furusawa, M., and Noce, T. 1994. Isolation of a DEAD-family protein gene that encodes a murine homolog of Drosophila vasa and its specific expression in germ cell lineage. Proc. Natl. Acad. Sci. 91: 12258-12262.

Ghirardelli, E. 1965. Differentiation of the germ cells and regeneration of the gonads in planarians. In Regeneration in animals and related problems (ed. V. Kiortsis and H.A.L. Trampusch), pp. 177-184. North-Holland, Amsterdam.

Gremigni, V. and Miceli, C. 1980. Cytophotometric evidence for cell 'transdifferentiation' in planarian regeneration. Wilhelm Roux's Arch. Dev. Biol. 188: 107-113.

Gremigni, V. and Puccinelli, I. 1977. A contribution to the problem of the origin of the blastema cells in planarians: A karyological and ultrastructural investigation. J. Exp. Zool. 199: 57-72.

Gremigni, V., Miceli, C., and Picano, E. 1980a. On the role of germ cells in planarian regeneration. II. Cytophotometric analysis of the nuclear Feulgen-DNA content in cells of regenerated somatic tissues. J. Embryol. Exp. Morphol. 55: 65-76.

Gremigni, V., Miceli, C., and Puccinelli, I. 1980b. On the role of germ cells in planarian regeneration. I. A karyological investigation. J. Embryol. Exp. Morphol. 55: 53-63. 
Gremigni, V., Nigro, M., and Puccinelli, I. 1982. Evidence of male germ cell redifferentiation into female germ cells in planarian regeneration. J. Embryol. Exp. Morphol. 70: 29-36.

Gruidl, M.E., Smith, P.A., Kuznicki, K.A., McCrone, J.S., Kirchner, J., Roussell, D.L., Strome, S., and Bennett, K.L. 1996. Multiple potential germ-line helicases are components of the germ-line-specific P granules of Caenorhabditis elegans. Proc. Natl. Acad. Sci. 93: 13837-13842.

Guan, K., Nayernia, K., Maier, L.S., Wagner, S., Dressel, R., Lee, J.H., Nolte, J., Wolf, F., Li, M., Engel, W., and Hasenfuss, G. 2006. Pluripotency of spermatogonial stem cells from adult mouse testis. Nature 440: 1199-1203.

Guo, T. 2007. "Functional analysis of genes involved in regulating stem cell maintenance and differentiation in the freshwater planarian Schmidtea mediterranea." Ph.D. thesis. University of Illinois, Urbana-Champaign.

Guo, T., Peters, A.H., and Newmark, P.A. 2006. A bruno-like gene is required for stem cell maintenance in planarians. Dev. Cell 11: 159-169.

Handberg-Thorsager, M. and Saló, E. 2007. The planarian nanos-like gene Smednos is expressed in germline and eye precursor cells during development and regeneration. Dev. Genes Evol. 217: 403-411.

Hay, E. and Coward, S. 1975. Fine structure studies on the planarian, Dugesia. I. Nature of the "neoblast" and other cell types in noninjured worms. J. Ultrastruct. Res. 50: 1-21.

Hay, B., Jan, L.Y., and Jan, Y.N. 1988. A protein component of Drosophila polar granules is encoded by vasa and has extensive sequence similarity to ATP-dependent helicases. Cell 55: $577-587$.

Hayashi, Y., Hayashi, M., and Kobayashi, S. 2004. Nanos suppresses somatic cell fate in Drosophila germ line. Proc. Natl. Acad. Sci. 101: 10338-10342.

Hayashi, T., Asami, M., Higuchi, S., Shibata, N., and Agata, K. 2006. Isolation of planarian X-ray-sensitive stem cells by fluorescence-activated cell sorting. Dev. Growth Differ. 48: 371-380.

Hayashi, K., de Sousa Lopes, S.M., and Surani, M.A. 2007. Germ cell specification in mice. Science 316: 394-396.

Higuchi, S., Hayashi, T., Hori, I., Shibata, N., Sakamoto, H., and Agata, K. 2007. Characterization and categorization of fluorescence activated cell sorted planarian stem cells by ultrastructural analysis. Dev. Growth Differ. 49: 571-581.

Hori, I. 1982. An ultrastructural study of the chromatoid body in planarian regenerative cells. J. Electron Microsc. 31: 63-72.

Hosokawa, M., Shoji, M., Kitamura, K., Tanaka, T., Noce, T., Chuma, S., and Nakatsuji, N. 2007. Tudor-related proteins TDRD1/MTR-1, TDRD6 and TDRD7/TRAP: Domain composition, intracellular localization, and function in male germ cells in mice. Dev. Biol. 301: 38-52.

Houston, D.W. and King, M.L. 2000. Germ plasm and molecular determinants of germ cell fate. Curr. Top. Dev. Biol. 50: $155-181$.

Hyman, L.H. 1951. The Invertebrates: Platyhelminthes and Rhynchocoela. The Acoelomate Bilateria. McGraw Hill, New York.

Iijima, I. 1884. Untersuchungen über den Bau und die Entwicklungsgeschichte der Süsswasser-Dendrocoelen (Tricladen). Z. Wiss. Zool. 40: 359-464.

Ikenishi, K. and Tanaka, T.S. 1997. Involvement of the protein of Xenopus vasa homolog (Xenopus vasa-like gene 1, $X V L G 1)$ in the differentiation of primordial germ cells. Dev. Growth Differ. 39: 625-633.

Inoue, T., Kumamoto, H., Okamoto, K., Umesono, Y., Sakai, M., Sánchez Alvarado, A., and Agata, K. 2004. Morphological and functional recovery of the planarian photosensing system during head regeneration. Zoolog. Sci. 21: $275-283$.

Johnson, A.D., Drum, M., Bachvarova, R.F., Masi, T., White, M.E., and Crother, B.I. 2003. Evolution of predetermined germ cells in vertebrate embryos: Implications for macroevolution. Evol. Dev. 5: 414-431.

Juliano, C.E., Voronina, E., Stack, C., Aldrich, M., Cameron, A.R., and Wessel, G.M. 2006. Germ line determinants are not localized early in sea urchin development, but do accumulate in the small micromere lineage. Dev. Biol. 300: 406-415.

Kai, T. and Spradling, A. 2004. Differentiating germ cells can revert into functional stem cells in Drosophila melanogaster ovaries. Nature 428: 564-569.

Kanatsu-Shinohara, M., Inoue, K., Lee, J., Yoshimoto, M., Ogonuki, N., Miki, H., Baba, S., Kato, T., Kazuki, Y., Toyokuni, S., et al. 2004. Generation of pluripotent stem cells from neonatal mouse testis. Cell 119: 1001-1012.

Kobayashi, S., Yamada, M., Asaoka, M., and Kitamura, T. 1996. Essential role of the posterior morphogen nanos for germline development in Drosophila. Nature 380: 708-711.

Komiya, T., Itoh, K., Ikenishi, K., and Furusawa, M. 1994. Isolation and characterization of a novel gene of the DEAD box protein family which is specifically expressed in germ cells of Xenopus laevis. Dev. Biol. 162: 354-363.

Kotaja, N., Bhattacharyya, S.N., Jaskiewicz, L., Kimmins, S., Parvinen, M., Filipowicz, W., and Sassone-Corsi, P. 2006. The chromatoid body of male germ cells: Similarity with processing bodies and presence of Dicer and microRNA pathway components. Proc. Natl. Acad. Sci. 103: 2647-2652.

Lasko, P.F. and Ashburner, M. 1988. The product of the Drosophila gene vasa is very similar to eukaryotic initiation factor-4A. Nature 335: 611-617.

Lawson, K.A., Dunn, N.R., Roelen, B.A., Zeinstra, L.M., Davis, A.M., Wright, C.V., Korving, J.P., and Hogan, B.L. 1999. Bmp4 is required for the generation of primordial germ cells in the mouse embryo. Genes Dev. 13: 42436.

Le Moigne, A. 1967. Présence d'émissions nucléaires fréquemment associées à des mitochondries dans les cellules embryonnaires des planaires. C.R. Soc. Biol. 161: 508-511.

Lehmann, R. and Nüsslein-Volhard, C. 1991. The maternal gene nanos has a central role in posterior pattern formation of the Drosophila embryo. Development 112: 679-691.

MacRae, E.K. 1967. The fine structure of sensory receptor processes in the auricular epithelium of the planarian, Dugesia tigrina. Z. Zellforsch. Mikrosk. Anat. 82: 479-494.

McLaren, A. 1981. Germ cells and soma: A new look at an old problem. Yale University Press, New Haven.

Mochizuki, K., Nishimiya-Fujisawa, C., and Fujisawa, T. 2001. Universal occurrence of the vasa-related genes among metazoans and their germline expression in Hydra. Dev. Genes Evol. 211: 299-308.

Morgan, T.H. 1902. Growth and regeneration in Planaria lugubris. Arch. Ent. Mech. Org. 13: 179-212.

Morita, M. and Best, J.B. 1984. Effects of photoperiods and melatonin on planarian asexual reproduction. J. Exp. Zool. 231: $273-382$

Morita, M., Best, J., and Noel, J. 1969. Electron microscopic studies of planarian regeneration. I. Fine structure of neoblasts in Dugesia dorotocephala. J. Ultrastruct. Res. 27: 7-23.

Newmark, P. and Sánchez Alvarado, A. 2000. Bromodeoxyuridine specifically labels the regenerative stem cells of planarians. Dev. Biol. 220: 142-153.

Newmark, P.A. and Sánchez Alvarado, A. 2002. Not your father's planarian: A classic model enters the era of functional genomics. Nat. Rev. Genet. 3: 210-219.

Newmark, P.A., Reddien, P.W., Cebria, F., and Sánchez Alvarado, A. 2003. Ingestion of bacterially expressed doublestranded RNA inhibits gene expression in planarians. Proc. Natl. Acad. Sci. (suppl. 1) 100: 11861-11865.

Nieuwkoop, P.D. and Sutasurya, L.A. 1979. Primordial germ cells in the chordates. Cambridge University Press, London.

Nieuwkoop, P.D. and Sutasurya, L.A. 1981. Primordial germ cells in the invertebrates: From epigenesis to preformation. Cambridge University Press, London.

Okamoto, K., Takeuchi, K., and Agata, K. 2005. Neural projections in planarian brain revealed by fluorescent dye tracing. Zoolog. Sci. 22: 535-546.

Olsen, L.C., Aasland, R., and Fjose, A. 1997. A vasa-like gene in zebrafish identifies putative primordial germ cells. Mech. Dev. 66: 95-105.

Orii, H., Sakurai, T., and Watanabe, K. 2005. Distribution of the stem cells (neoblasts) in the planarian Dugesia japonica. Dev. 
Genes Evol. 215: 143-157.

Palakodeti, D., Smielewska, M., Lu, Y.C., Yeo, G.W., and Graveley, B.R. 2008. The PIWI proteins SMEDWI-2 and SMEDWI-3 are required for stem cell function and piRNA expression in planarians. RNA 14: 1174-1186.

Pigon, A., Morita, M., and Best, J.B. 1974. Cephalic mechanism for social control of fissioning in planarians. II. Localization and identification of the receptors by electron micrographic and ablation studies. J. Neurobiol. 5: 443-462.

Ptashne, M. 2007. On the use of the word 'epigenetic'. Curr. Biol. 17: R233-R236.

Rando, T.A. 2006. Stem cells, ageing and the quest for immortality. Nature 441: 1080-1086.

Raz, E. 2003. Primordial germ-cell development: The zebrafish perspective. Nat. Rev. Genet. 4: 690-700.

Reddien, P.W. and Sánchez Alvarado, A. 2004. Fundamentals of planarian regeneration. Annu. Rev. Cell Dev. Biol. 20: 725-757.

Reddien, P.W., Bermange, A.L., Murfitt, K.J., Jennings, J.R., and Sánchez Alvarado, A. 2005a. Identification of genes needed for regeneration, stem cell function, and tissue homeostasis by systematic gene perturbation in planaria. Dev. Cell 8: 635-649.

Reddien, P.W., Oviedo, N.J., Jennings, J.R., Jenkin, J.C., and Sánchez Alvarado, A. 2005b. SMEDWI-2 is a PIWI-like protein that regulates planarian stem cells. Science 310: 1327-1330.

Robb, S.M., Ross, E., and Sánchez Alvarado, A. 2008. SmedGD: The Schmidtea mediterranea genome database. Nucleic Acids Res. 36: D599-D606.

Rossi, L., Salvetti, A., Lena, A., Batistoni, R., Deri, P., Pugliesi, C., Loreti, E., and Gremigni, V. 2006. DjPiwi-1, a member of the PAZ-Piwi gene family, defines a subpopulation of planarian stem cells. Dev. Genes Evol. 216: 335-346.

Saló, E. and Baguñà, J. 1984. Regeneration and pattern formation in planarians. I. The pattern of mitosis in anterior and posterior regeneration in Dugesia $(G)$ tigrina, and a new proposal for blastema formation. J. Embryol. Exp. Morphol. 83: 63-80.

Saló, E. and Baguñà, J. 1989. Regeneration and pattern formation in planarians. II. Local origin and role of cell movements in blastema formation. Development 107: 69-76.

Salvetti, A., Rossi, L., Deri, P., and Batistoni, R. 2000. An MCM2-related gene is expressed in proliferating cells of intact and regenerating planarians. Dev. Dyn. 218: 603-614.

Salvetti, A., Rossi, L., Lena, A., Batistoni, R., Deri, P., Rainaldi, G., Locci, M.T., Evangelista, M., and Gremigni, V. 2005. DjPum, a homologue of Drosophila Pumilio, is essential to planarian stem cell maintenance. Development 132: 1863-1874.

Sánchez Alvarado, A. 2006. Planarian regeneration: Its end is its beginning. Cell 124: 241-245.

Sánchez Alvarado, A. and Newmark, P.A. 1999. Doublestranded RNA specifically disrupts gene expression during planarian regeneration. Proc. Natl. Acad. Sci. 96: 5049-5054.

Sánchez Alvarado, A., Newmark, P.A., Robb, S.M., and Juste, R. 2002. The Schmidtea mediterranea database as a molecular resource for studying platyhelminthes, stem cells and regeneration. Development 129: 5659-5665.

Santos, A.C. and Lehmann, R. 2004. Germ cell specification and migration in Drosophila and beyond. Curr. Biol. 14: R578-R589.

Sato, K., Shibata, N., Orii, H., Amikura, R., Sakurai, T., Agata, K. Kobayashi, S., and Watanabe, K. 2006. Identification and origin of the germline stem cells as revealed by the expression of nanos-related gene in planarians. Dev. Growth Differ. 48: 615-628.

Sauzin, M.-J. 1968. Présence d'émissions nucléaires dans les cellules différenciées et en différenciation de la planaire adulte Dugesia gonocephala. C.R. Acad. Sci. 267: 1146-1148.

Schultz, E. 1904. Über Reduktionen. I. Über Hungerserscheinungen bei Planaria lactea. Arch. Entwicklungsmech. Org. 18: $555-577$.
Seandel, M., James, D., Shmelkov, S.V., Falciatori, I., Kim, J., Chavala, S., Scherr, D.S., Zhang, F., Torres, R., Gale, N.W., et al. 2007. Generation of functional multipotent adult stem cells from GPR $125^{+}$germline progenitors. Nature 449: 346-350.

Sengel, C. 1960. Culture in vitro de blastèmes de régénération de Planaires. J. Embryol. Exp. Morphol. 8: 468-476.

Seydoux, G. and Braun, R.E. 2006. Pathway to totipotency: Lessons from germ cells. Cell 127: 891-904.

Seydoux, G. and Schedl, T. 2001. The germline in C. elegans: Origins, proliferation, and silencing. Int. Rev. Cytol. 203: 139-185.

Seydoux, G. and Strome, S. 1999. Launching the germline in Caenorhabditis elegans: Regulation of gene expression in early germ cells. Development 126: 3275-3283.

Shibata, N., Umesono, Y., Orii, H., Sakurai, T., Watanabe, K. and Agata, K. 1999. Expression of vasa (vas)-related genes in germline cells and totipotent somatic stem cells of planarians. Dev. Biol. 206: 73-87.

Silveira, M. and Porter, K.R. 1964. The spermatozoids of flatworms and their microtubular systems. Protoplasma 59: 240-265.

Starz-Gaiano, M. and Lehmann, R. 2001. Moving towards the next generation. Mech. Dev. 105: 5-18.

Suzuki, A., Tsuda, M., and Saga, Y. 2007. Functional redundancy among Nanos proteins and a distinct role of Nanos2 during male germ cell development. Development 134: 77-83.

Tanaka, S.S., Toyooka, Y., Akasu, R., Katoh-Fukui, Y., Nakahara, Y., Suzuki, R., Yokoyama, M., and Noce, T. 2000. The mouse homolog of Drosophila Vasa is required for the development of male germ cells. Genes Dev. 14: 841-853.

Toyooka, Y., Tsunekawa, N., Takahashi, Y., Matsui, Y., Satoh, M., and Noce, T. 2000. Expression and intracellular localization of mouse Vasa-homologue protein during germ cell development. Mech. Dev. 93: 139-149.

Tsuda, M., Sasaoka, Y., Kiso, M., Abe, K., Haraguchi, S., Kobayashi, S., and Saga, Y. 2003. Conserved role of nanos proteins in germ cell development. Science 301: 1239-1241.

Tsunekawa, N., Naito, M., Sakai, Y., Nishida, T., and Noce, T. 2000. Isolation of chicken vasa homolog gene and tracing the origin of primordial germ cells. Development 127: 2741-2750.

Wang, C. and Lehmann, R. 1991. Nanos is the localized posterior determinant in Drosophila. Cell 66: 637-647.

Wang, Y., Zayas, R.M., Guo, T., and Newmark, P.A. 2007. nanos function is essential for development and regeneration of planarian germ cells. Proc. Natl. Acad. Sci. 104: 5901-5906.

Weismann, A. 1893. The germ-plasm. A theory of heredity (transl. W.N. Parker and H. Rönnfeldt). Charles Scribner's Sons, New York

Wolfe, S.A., Anderson, J.V., Grimes, S.R., Stein, G.S., and Stein, J.S. 1989. Comparison of the structural organization and expression of germinal and somatic rat histone $\mathrm{H} 4$ genes. Biochim. Biophys. Acta 1007: 140-150.

Ying, Y., Liu, X.M., Marble, A., Lawson, K.A., and Zhao, G.Q. 2000. Requirement of $B m p 8 b$ for the generation of primordial germ cells in the mouse. Mol. Endocrinol. 14: 1053-1063.

Yoon, C., Kawakami, K., and Hopkins, N. 1997. Zebrafish vasa homologue RNA is localized to the cleavage planes of 2- and 4-cell-stage embryos and is expressed in the primordial germ cells. Development 124: 3157-3165.

Yoshida-Kashikawa, M., Shibata, N., Takechi, K., and Agata, K. 2007. DjCBC-1, a conserved DEAD box RNA helicase of the $\mathrm{RCK} / \mathrm{p} 54 / \mathrm{Me} 31 \mathrm{~B}$ family, is a component of RNA-protein complexes in planarian stem cells and neurons. Dev. Dyn 236: 3436-3450.

Zayas, R.M., Hernandez, A., Habermann, B., Wang, Y., Stary, J.M., and Newmark, P.A. 2005. The planarian Schmidtea mediterranea as a model for epigenetic germ cell specification: Analysis of ESTs from the hermaphroditic strain. Proc. Natl. Acad. Sci. 102: 18491-18496. 


\title{
$\$_{\text {CSH\& }}^{\infty}$ Cold Spring Harbor Symposia SYMPOSIA
}

\section{Germ Cell Specification and Regeneration in Planarians}

\author{
P.A. Newmark, Y. Wang and T. Chong
}

Cold Spring Harb Symp Quant Biol 2008 73: 573-581 originally published online November 6, 2008 Access the most recent version at doi:10.1101/sqb.2008.73.022

References This article cites 109 articles, 27 of which can be accessed free at: http://symposium.cshlp.org/content/73/573.full.html\#ref-list-1

License

Email Alerting Receive free email alerts when new articles cite this article - sign up in the Service box at the top right corner of the article or click here. 